\title{
REPTILES
}

\section{MAJOR SLUMP EVENTAT GRASSLANDS NATIONAL PARK SNAKE PIT IN SOUTHWESTERN SASKATCHEWAN}

Laura E. Gardiner ${ }^{1,2}$ and Kendall W. Sonmor ${ }^{3}$

${ }^{1}$ Department of Biology, University of Regina, Regina, SK, S4S 0A2; E-mail: <gardilau@gmail.com>

${ }^{2}$ Royal Saskatchewan Museum, Regina, SK, S4P 2V7

3Parks Canada, Val Marie, SK, SON 2T0; E-mail: <kendall.sonmor@gmail.com> or <robert.sissons@pc.gc.ca>

\section{Introduction}

The availability of suitable winter hibernacula for snakes is critical to their persistence at higher latitudes. ${ }^{1-4}$ Southwestern Saskatchewan is home to multiple snake species living at the northern extent of their geographic range in North America. These snakes rely on unstable slump zones, mammal burrows, rock crevices, and abandoned cisterns to provide suitable over-wintering sites that enable them to survive the harsh winter. ${ }^{5,6}$ It is common to find more than one species hibernating together at communal hibernation sites, which may be a response to limited availability of suitable locations for over-wintering. Communal hibernation places large numbers of snakes of multiple species together at single locations for prolonged periods when they are immobile, and therefore highly vulnerable. Disturbance or destruction of over-wintering sites by natural or anthropogenic factors may cause significant reductions in population size, especially for species that are already rare, such as the eastern yellow-bellied racer (Coluber constrictor flaviventris). ${ }^{7}$ Here we describe occlusion of hibernaculum openings due to natural erosion, and potential loss of 'Snake Pit', one of the largest and most important overwintering sites for snakes in Grasslands National Park, Saskatchewan.

\section{Study Site}

The Frenchman River Valley in southwest Saskatchewan was formed by glacial melt-water. ${ }^{8}$ Landslides, or 'slumps', are the dominant process of valley widening, and are common along melt-water valleys and tributaries. ${ }^{9}$ The Frenchman River Valley is $80 \mathrm{~m}$ shallower and almost three times as wide as the original melt-water channel due to the accumulation of landslide debris. ${ }^{8}$ Slumping along unstable slopes creates terraces containing slight depressions or sinkholes, fissures or small faults, and loosely packed soil that attracts burrowing mammals. ${ }^{4}$ These factors provide plentiful opportunities for snakes to find refuge below the frost line, making unstable slump zones a common location for winter hibernation sites in the area.

'Snake Pit' is a well-known hibernaculum located in the Frenchman 

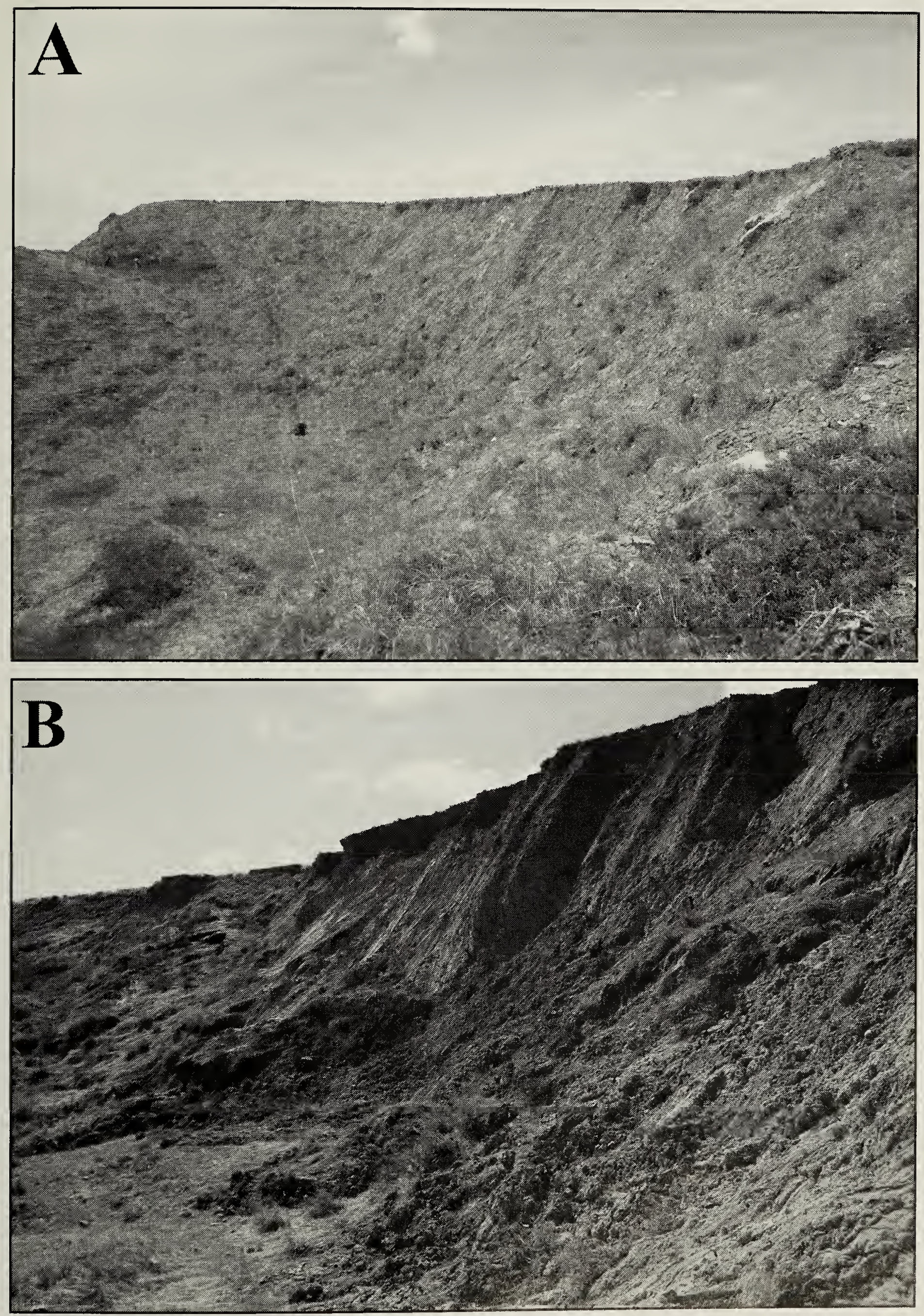

Figure 1. Snake Pit hibernaculum in Grasslands National Park, SK, (A) before (May 2010) and (B) after (May 2011) the slump event along the back slope. The resulting debris occluded den entrances prior to typical spring emergence, trapping snakes in the hibernaculum. Photos by Laura Gardiner (A) and Danae Frier (B) 
River Valley in Grasslands National Park, Saskatchewan. It is an established slump-based hibernaculum inhabited by prairie rattlesnakes (Crotalus viridis), plains garter snakes (Thamnophis radix), eastern yellow-bellied racers, and bullsnakes (Pituophis catenifer sayi). Historically, the site has been subjected to instability due to both natural and anthropogenic disturbances. This site is the largest active snake den in the Val Marie area, known to contain large numbers of rattlesnakes since the establishment of the local community (K. Grant, Parks Canada, pers. comm.). It has also been recognized in several major reptile surveys in the area dating back to the late 1980 's. ${ }^{10,11}$ In the past, humans have attempted to eliminate snakes at Snake Pit using a variety of methods. These include use of dynamite to destroy dens, vandalism by shotgun, and physical mutilation resulting in observations of headless and rattle-less snakes..$^{10,12}$ The snakes at this location were formally protected under federal law within Grasslands National Park in 2001.

\section{Erosion Event at Snake Pit in 2011}

In the spring of 2011, Snake Pit was seriously damaged by a large slump event that was triggered by soil saturation (Fig. 1b). Excessive water in the soil caused a large amount of sediment to slide down the back slope of the den coulee, covering previously existing entrances to hibernation sites. There were previously at least 10 active entrance holes at this site. ${ }^{10}$ Along the back slope where the slump occurred, at least six holes were observed in 2010. After the slump event, only one hole was observed on the slope. The slump extended from the top of the slope to the bottom and was estimated to be $120 \mathrm{~m}$ across; there was approximately $2 \mathrm{~m}$ of debris deposited at the bottom of the slope (Fig. 2). The slumping occurred in early April, about a month before typical spring emergence, and likely trapped snakes inside of the hibernaculum.

In early May 2011, fewer snakes than usual were observed during research activities at Snake Pit, and many of the snakes that were observed were covered in mud. A remote motion-detecting camera was set up on the single remaining hole from 3 to 16 May. Review of the images revealed at least one rattlesnake using this hole. During the spring den survey following the slump in 2011, a maximum of 4 racers were caught per day, while surveys in 2010 had resulted in up to 16 racers per day at Snake Pit. Slumping also occurred to various extents at or near four of seven other known hibernacula within Grasslands National Park, although no other site experienced slumping to the same scale or level of destruction as was observed at Snake Pit.

\section{Discussion}

The eastern yellow-bellied racer, an inhabitant of the Snake Pit hibernaculum, is a COSEWIC-designated Threatened species in Canada, with a known range confined to the Frenchman River Valley and Big Muddy Valley in southern Saskatchewan, and the Milk River Valley in southeastern Alberta. ${ }^{5,6,13}$ As of 2011, Snake Pit contained the largest known population of racers in Canada, and was therefore a very important site for this species. ${ }^{5,13}$ Mark-recapture estimates using the Lincoln-Peterson formula (four recaptures of 40 previously marked snakes in a sample of 17 snakes caught in 2011) suggest a $50 \%$ decrease in the racer population at Snake Pit from 2010 to 2011 (J. Martino, L. Gardiner, unpublished data). ${ }^{13}$ The slump event may represent an important loss of individuals from the largest known population of eastern yellow-bellied racers in Canada. The event may have similarly affected other species using this den, although we have 


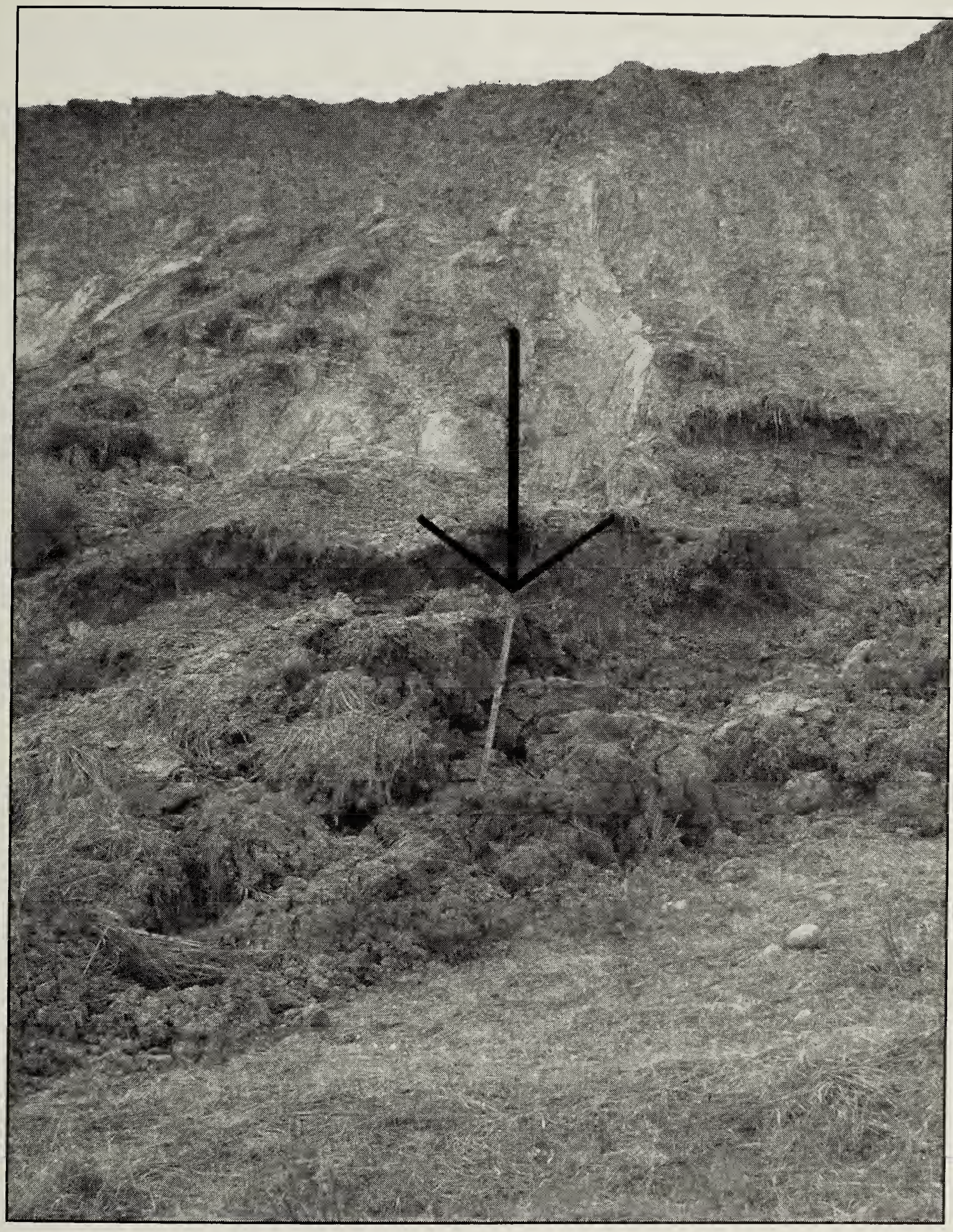

Figure 2 Metre stick (arrow) showing the amount of debris that slumped at Snake Pit. The slump was estimated at $120 \mathrm{~m}$ across resulting in $2 \mathrm{~m}$ of debris deposited at the bottom of the slope. 
minimal data on the magnitude of this effect.

Large mortality events in small peripheral populations, such as those of snakes in southern Saskatchewan, have the potential to cause extirpation and genetic isolation, making them more susceptible to environmental perturbations. ${ }^{6}$ As such, the potential decimation of the largest known population of racers in Canada may have negative consequences for the management of this Threatened species. At this time, additional search effort is needed to locate more racer dens in Canada in order to fully understand the conservation significance of this event to the species. The implications of this event to the other species concentrated at this site are currently unknown and warrant additional research.

1. Gannon V (1978) Factors limiting the distribution of the prairie rattlesnake. Blue Jay 36:142-144.

2. Rosen PC (1991) Comparative ecology and life history of the racer (Coluber constrictor) in Michigan. Copeia 1991:897-909.

3. Prior KA, Weatherhead PJ (1996) Habitat features of black rat snake hibernacula in Ontario. Journal of Herpetology 30:211-218.

4. Nicholson J, Selwyn R (2001) Utilization of air photo interpretation to locate prairie rattlesnake (Crotalus viridis viridis) hibernacula in the south Saskatchewan River Valley. Alberta Sustainable Resource Development, Fisheries and Wildife Management Division. Alberta Species at Risk Report No. 22. Edmonton, AB.

5. Parks Canada Agency (2010) Recovery Strategy for Eastern Yellow-bellied Racer (Coluber constrictor flaviventris) in Canada. Species at Risk Act Recovery Strategy Series. Parks Canada Agency. Ottawa, ON.

6. COSEWIC (Committee on the Status of Endangered Wildife in Canada) (2004) COSEWIC assessment and update status report on the Eastern and Western Yellow-bellied Racers, Coluber constrictor flaviventris and Coluber constrictor mormon in Canada. COSEWIC. Ottawa, ON.

7. Shine R, Mason RT (2004) Patterns of mortality in a cold-climate population of garter snakes (Thamnophis sirtalis parietalis). Biological Conservation 120:205214.

8. Christainsen EA, Sauer EK (1988) Age of the Frenchman Valley and associated drift south of the Cypress Hills, Saskatchewan, Canada. Canadian Journal of Earth Sciences 25:1703-1708.

9. Sauchyn DJ, Nelson HL (1999) The origin and erosion of Police Point landslide, Cypress Hills, southeastern Alberta. In: Lemmen DS, Vance RE (eds) Holocene climate and environmental change in the Palliser Triangle: a geoscientific context for evaluating the impacts of climate change on the southern Canadian Prairies. Geological Survey of Canada Bulletin 534, Ottawa, ON, p 257-265.

10. Mackay R (1987) A survey of snake hibernacula in the Val Marie area. Unpublished report for the Saskatchewan Natural History Society, Saskatoon, SK.

11. Macartney M, Weichel B (1993) Population status and biology of the prairie rattlesnake and other reptile species in southwest Saskatchewan 19901991. Johnson and Weichel Resource Management Consultants. Saskatoon, SK.

12. Finley KJ, Jasieniuk MA (1978) The eastern yellow-bellied racer in Canada. Blue Jay 36:88-91.

13. Gardiner LE, Martino JA, Poulin RG, Somers CM (2011) Updated status of eastern yellow-bellied racer populations in the Canadian Prairies. Blue Jay 69:70-74

Man's heart away from nature becomes hard.

- Standing Bear 